\title{
Abrasion surfaces on internal moulds of ammonites as palaeobathymetric indicators
}

\author{
S. Fernández-López ${ }^{\mathrm{a}}, \mathrm{G}$. Meléndez ${ }^{\mathrm{b}}$ \\ ' Departamento de Paleontologia, Facultad de Ciencias Geológicas, Universidad Complutense de Madrid, 28040 Madrid, \\ Spain \\ ${ }^{b}$ Laboratorio de Paleontologia, Departamento de Geologia, Facultad de Ciencias, Universidad de Zaragoza, \\ 50009 Zaragoza, Spain
}

Received 2 March 1993; revised and accepted 19 October 1993

\begin{abstract}
Some abrasion surfaces displayed by internal moulds of ammonites, such as annular abrasion furrows formed on the venter surface and ellipsoidal abrasion facets preferentially developed on the last third part of the preserved whorl, are diagnostic criteria of taphonomic reworking. These taphonomic criteria indicate that the internal moulds have been exhumed and moved before their final burial. We explain the origin of these abrasion surfaces by the action of directional (non oscillatory) currents in very shallow water, most probably in intertidal environments. The distribution of ammonite moulds displaying such preservational features is correlated with the changes in the facies and the trend of the sedimentary sequences. Taphonomic analysis of Jurassic ammonites of the Iberian Range underlines the importance and usefulness of taphonomic gradients in sequence stratigraphy and palaeogeographic reconstructions.
\end{abstract}

\section{Introduction}

Evidence of reworking is particularly interesting in Sedimentology and sequence stratigraphy, as reworking processes are usually associated with the development of stratigraphic discontinuities. Even though reworked fossils can neither be used to establish nor to identify biostratigraphic or chronostratigraphic units (N.A.C.S.N., 1983), they are a useful tool for palaeontological and sequential analysis, and can supply a great deal of information about the source areas of sediments, as indicators of palaeocurrents and for the reconstruction of sedimentary environments and palaeogeography (Stanley, 1965, 1966; Needham et al., 1969; Henderson and McNamara, 1985; Baird and Brett, 1986; Eshet et al., 1988; Scott and Medioli,
1988; Traverse, 1988; Fernández-López and Gómez, 1990b; McCaffrey et al., 1992). Some reworked fossils, as the only existing record of eroded sediments, even provide palaeontological and sedimentological data about episodes which are not otherwise represented in the stratigraphic record.

Taphonomic analysis carried out on Jurassic ammonites of the Iberian Range, Spain (Fig. 1), have shown the relevance of some diagnostic criteria to identify and interpret reworked fossils. Some reworked ammonites display specific abrasion surfaces which are significant for palaeobathymetric reconstructions, since they result from taphonomic alteration processes occurring under very shallow environmental conditions, most probably in intertidal environments. This is the case 


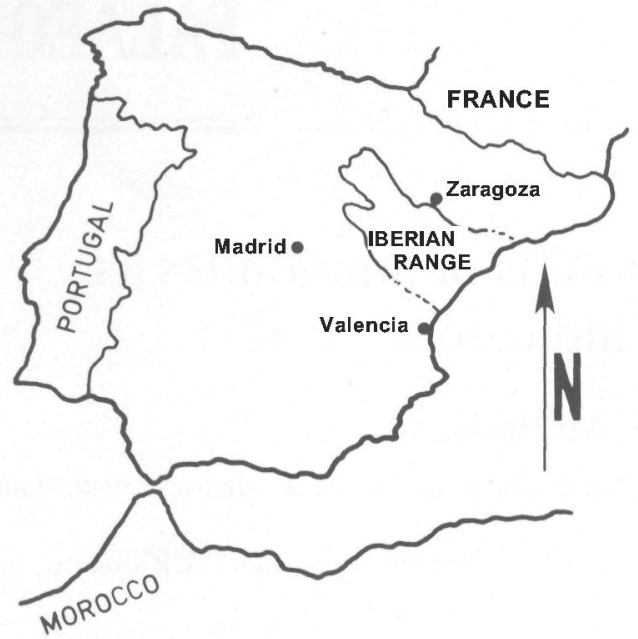

Fig. 1. Geographic setting of the Iberian Range within the Iberian Peninsula.

for (1) the so-called ellipsoidal abrasion facets developed preferentially on the last third of the last preserved whorl and (2) the annular abrasion furrows carved on the venter surface.

Internal moulds of ammonites showing so-called ellipsoidal abrasion facets or annular abrasion furrows are quite common at some levels of the Middle Jurassic of the Iberian Range, and they become even more abundant near the Middle-Upper Jurassic boundary. This phenomenon has been mentioned by several authors (Fernández-López, 1985a,b; Aurell, 1990; Aurell and Melếndez, 1990; Fernández-López and Gómez, 1990b; Meléndez et al., 1990; Aurell et al., 1992).

The purpose of this paper is to show the characters of these abrasion surfaces and to discuss the importance of reworked fossils as palaeobathymetric and palaeoenvironmental indicators.

\section{Description of ellipsoidal facets and annular furrows}

Two different categories of wear surfaces can be distinguished, according to their position on the ammonite mould: (1) ellipsoidal facets, affecting the venter surface and some portions of the whorl sides, and restricted to, or preferentially developed on, the last third of the last whorl and, (2) annular furrows carved on the venter surface of the internal mould and which are preferentially developed on the last third of the last whorl (Fig. 2). Ellipsoidal facets display some particular features, such as: they are mostly restricted to the last third of the preserved whorl; they are wider on one side than on the other; and they are also shallower, more asymmetric with respect to the sagittal plane of the shell, and have sharper edges than annular furrows (Fig. 3).

These facets and furrows can occur on internal moulds of complete shells as well as on incomplete phragmocones. In both cases the maximum depth of the wear surfaces occurs on the venter, on the last third of preserved whorl. Some specimens showing evidence of an ellipsoidal facet on the last third of the last preserved whorl also display a furrow carved into the whole venter surface (Fig. 4).

Internal moulds bearing wear surfaces of each of these categories maintain their original shape without showing any evidence of extensive compression or crushing by diagenetic compaction. The filling of these fossils is petrographically discontinuous with the fabric of the enclosing carbonate rock. Ammonites bearing ellipsoidal facets or annular furrows from the Middle-Upper Jurassic oolitic ironstone level in the Iberian Range, for example, are enclosed in a ferruginous oolitic

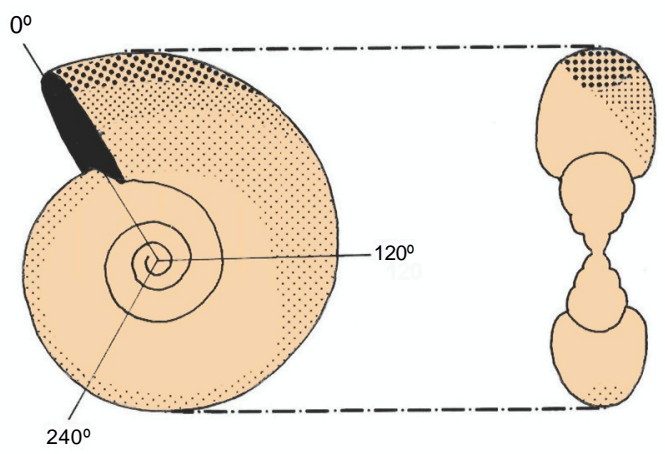

Fig. 2. Diagram of an internal mould of an ammonite showing the different frequencies of distribution of these wear surfaces. Areas with denser points display higher frequencies. The maximum values occur on the last third, and on the venter surface, of the last whorl. Some specimens show a furrow carved on the whole venter. 

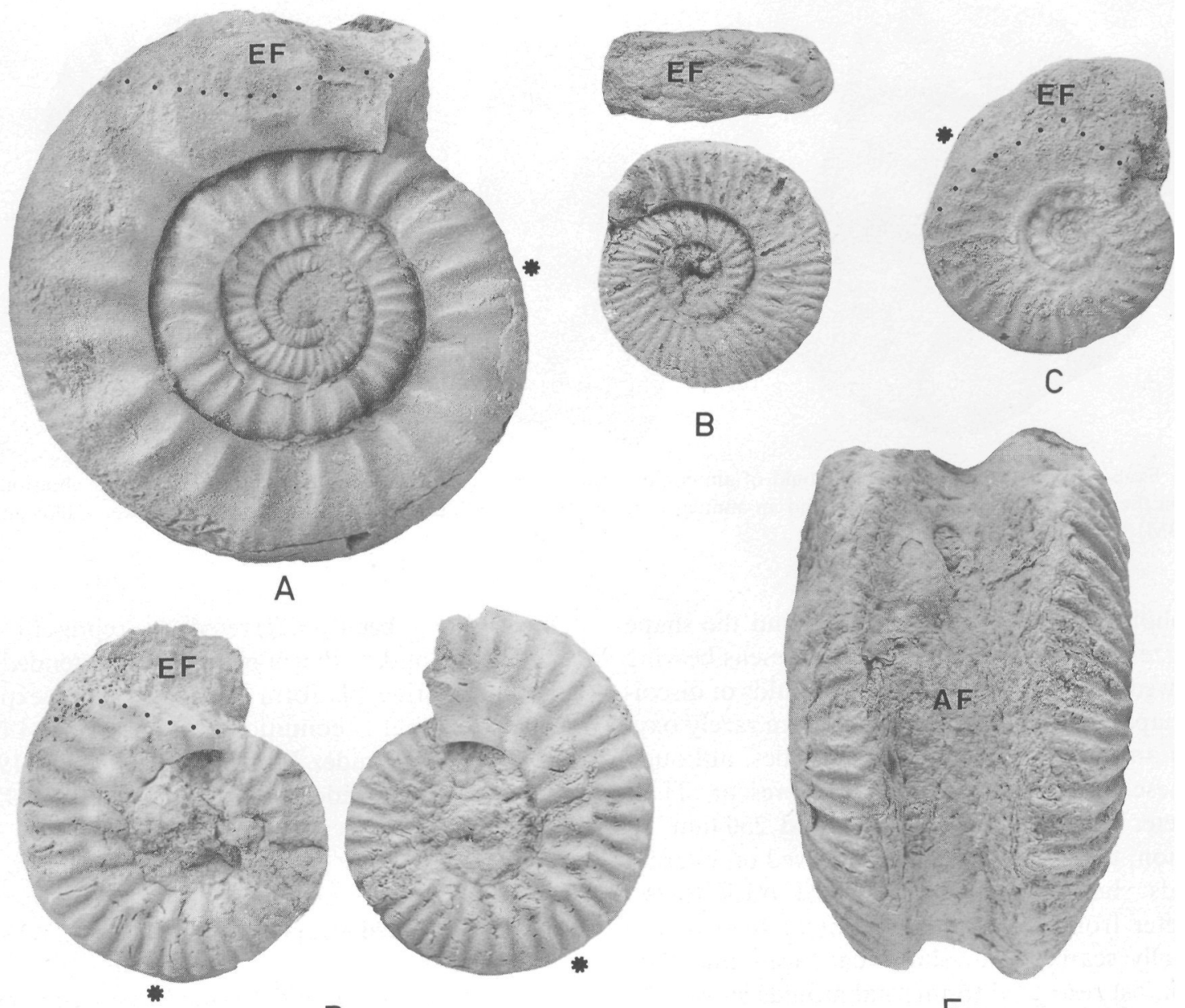

D

$E$

Fig. 3. Examples of reworked internal moulds of ammonites with ellipsoidal abrasion facets $(E F)$ or annular abrasion furrows $(A F)$, from the Middle Jurassic of Iberian Range. (A) Subgrossouvria recuperoi (Gemmellaro), lower Callovian (Casas de Bucar, Teruel, Col. SFL, CB164/3). (B)Alligaticeras (Properisphinctes) sp., lower Oxfordian (Griegos, Teruel, Col. SFL, GR168/1). (C) Ludwigella sp., upper Aalenian (Pinilla del Campo, Soria, Col. SFL, 4PV/5). (D) Chanasia sp., Callovian (La Olmeda, Cuenca, Col. SFL, LM166/1). (E) Macrocephalites sp., lower Callovian (Moscardon, Teruel, Col. SFL, 4M166/2), note the ornamentation preserved on both sides of the ammonite contrasting with the sharp borders of the furrow. All figures natural size. The beginning of the body chamber is indicated by an asterisk.

wackestone matrix but usually display a nonoolitic micritic sedimentary infilling (Fig. 5A). These fossils may also show other distinctive features such as phosphatic cements or iron coatings.

Ellipsoidal facets and annular furrows cut the fabric of the internal moulds and have a counterpart impression in the enclosing rock. These wear surfaces are more pronounced on the venter of the internal moulds than on the whorl sides. The surfaces of the facets and furrows are sharp and irregular, and usually concave, even if the outer surface of the mould is well defined and the ornamentation is preserved almost undisturbed on the whorl sides. A line, sometimes a sharp edge, can be easily discerned separating both surfaces. The texture of both surfaces may be covered by a thin ferruginous patina or coating.

A close correlation can be drawn between the 

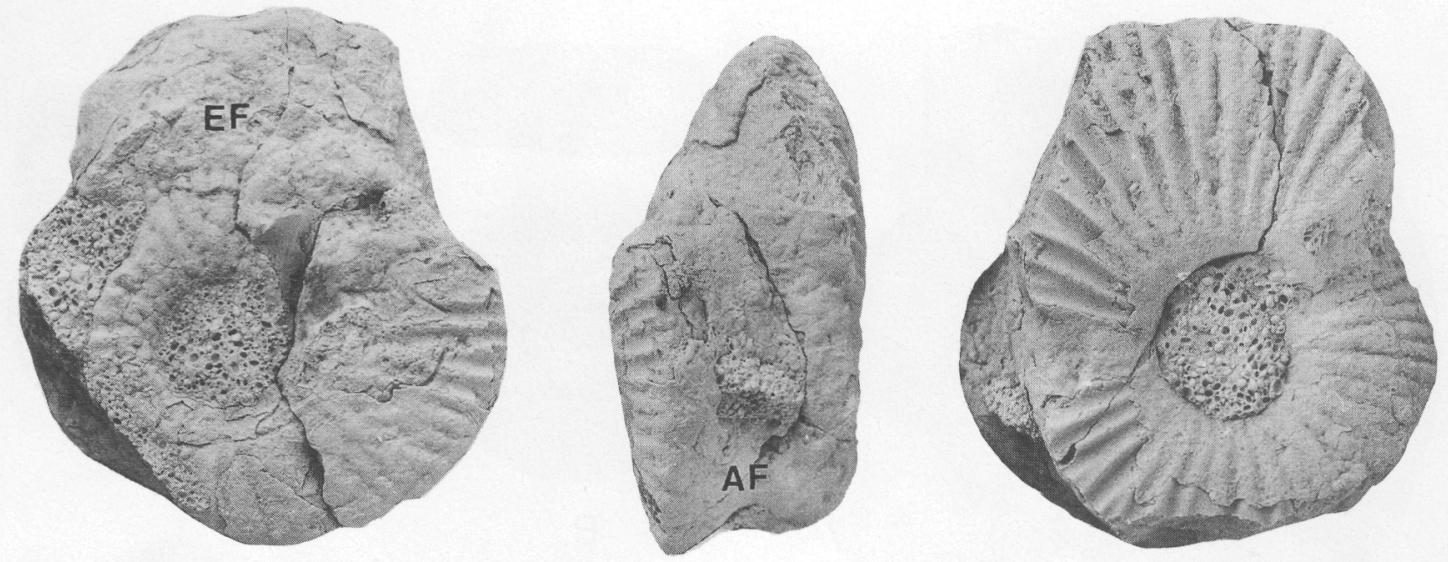

Fig. 4. Example of a reworked internal mould of ammonites, Macrocephalites sp., showing traces of an ellipsoidal abrasion facet $(E F)$ on the last third of preserved whorl and an annular abrasion furrow $(A F)$ carved on the whole venter. Lower Callovian $($ Col. SFL, 3M166/4). x 1 .

morphology of these wear surfaces and the shape and size of the internal moulds. Specimens bearing such wear surfaces are planispiral moulds of discoidal shape, frequently platycones, more rarely oxycones and never globular sphaerocones, although all these morphological types are present. Their diameter may range between 20 and $250 \mathrm{~mm}$. In addition, they have only been observed on internal moulds showing a ratio of whorl thickness to diameter from 0.20 to 0.60 . Annular furrows are generally scarcer than ellipsoidal facets and they are almost restricted to internal moulds showing a higher ratio of thickness to diameter, between 0.35 and 0.60 .

These fossils can display varied orientations with respect to bedding planes of the strata in which they are enclosed. This orientation varies from horizontal to vertical, but the position of the facet does not correspond to the bedding planes of the strata, and the geopetal structures of the internal moulds are not consistent with the present orientation of the fossils or with respect to the depositional surface.

In the Iberian Range, the reworked ammonites bearing ellipsoidal abrasion facets or annular abrasion furrows usually occur in carbonate rocks, most commonly associated with indurated surfaces, ranging from firmgrounds to hardgrounds. These surfaces show a distribution of over tens of kilometers and locally display mud cracks. These facies have been interpreted to represent very shallow subtidal environments of an extended carbonate marine platform locally at times exposed to subaerial conditions (Fernández-López, 1985b,c; Fernández-López and Gómez, 1990a; Aurell and Meléndez, 1990; Aurell et al., 1992).

\section{Resedimented vs. reworked fossils}

A distinction should be made between resedimented fossils and reworked fossils (reelaborated fossils sensu Fernández-López, 1985a, 1991a). Taphonomic resedimentation means the displacement on the substrate surface of remains of organisms before their burial. On the other hand, taphonomic reworking means the exhumation and displacement on the substrate surface of previously buried remains of organisms. Both taphonomic processes, resedimentation and reworking, are particular cases of remobilization processes involving or not transport of the remains.

In many cases, reworked and resedimented remains can eventually be buried together and may be found associated in the same bed. In the case of ammonites, reworked fossils are older than those resedimented, and the age of the bed containing a mixed assemblage of this kind is that of the resedimented fossils. 


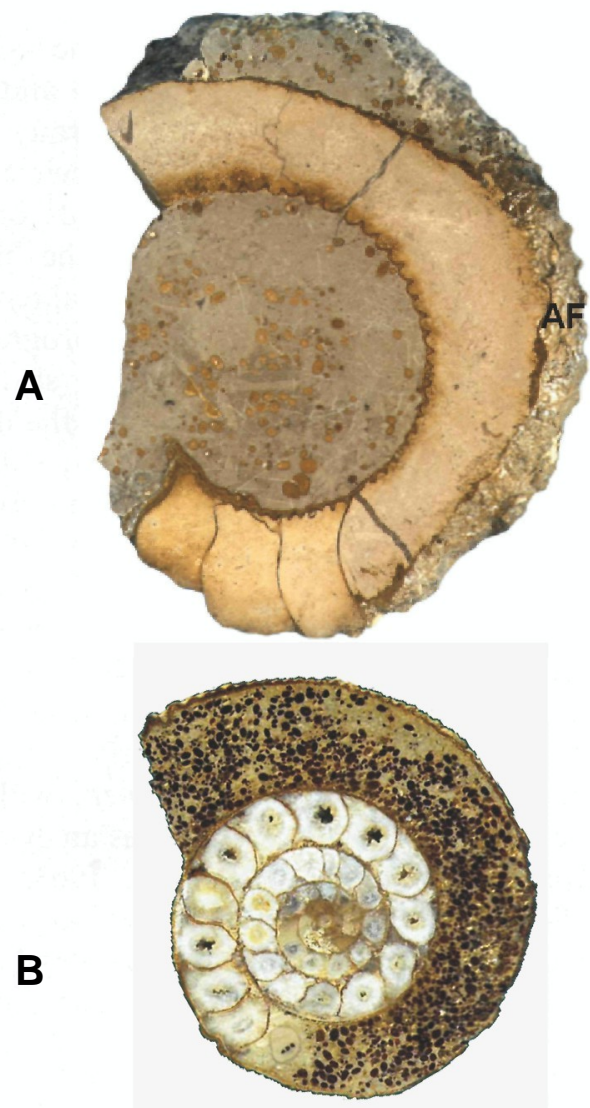

Fig. 5. Polished section of a reworked internal mould (A), bearing an annular abrasion furrow $(A F)$ on the venter surface. The sedimentary infilling of the last three chambers of the phragmocone and body chamber respectively is a non-oolitic micritic limestone, whereas the enclosing rock is a wackestone containing common iron ooids. Macrocephalites sp. Lower Callovian (Moscardon, Teruel, Col. SFL, 3M166/8). x 1. Conversely, the specimen B is a resedimented shell and shows a sedimentary infilling with iron ooids similar to the sedimentary rock in which was found. Perisphinctid, Oxfordian (Moscardon, Teruel, Col. SFL., 3M168/5). x 1.

\section{Diagnostic criteria for taphonomic reworking}

Reworked fossils may be difficult to recognize. In the case of ammonites, however, basic criteria to identify taphonomic reworking have been summarized by one of the authors (Fernández-López, 1985a). Generally, the sediment comprising the reworked internal moulds is physically and petrographically discontinuous with the fabric of the enclosing rocks (Fig. 5A). Some internal moulds are also identifiable as reworked fossils because, during the reworking process and before the final burial, they have developed some other diagnostic features such as coating by iron-crusts (Figs. 3E and $5 \mathrm{~A}$ ), disarticulation surfaces along the boundary between contiguous chambers of the phragmocone or between the phragmocone and the body chamber (Fig. 3C), as well as traces of bioerosion or encrusting organisms and those abrasion surfaces here discussed.

Within a carbonate shallowing upwards sequence, the lower levels contain a higher proportion of clay and marl than of carbonate. In these lower levels, the sedimentary filling of fossils deposited coeval with the sediment did not undergo early cementation and will be affected by diagenetic compaction. Reworked ammonites from the same association usually differ from resedimented ammonites by the lack of evidence of extensive compression, as they were already cemented before being included in the new sediment. Some other criteria, such as the inconsistency between the geopetal structures of the internal moulds and the depositional polarity of the enclosing bed, are also indicative of concretionary internal moulds having been exhumed and moved before their final burial.

\section{Interpretation of abrasion surfaces}

Resedimentation or rolling of the shell on the substrate can lead to the generation of broken shells, preferentially fragmented at the peristomal region. However, in such cases a continuous transition can be observed near the fractures between the sedimentary filling and the enclosing rock. Conversely, the surface of the ellipsoidal surfaces and annular furrows is, in fact, a discontinuity surface between the sedimentary filling and the matrix.

The process of filling by sediment of the cephalopods shells has been the subject of detailed studies by several authors (e.g., Seilacher, 1968, 1971; Mundlos, 1970; Duringer, 1982). Draught filling (intra-cameral draught stream created by external turbulence through constricted siphuncular openings, in Seilacher, 1968) often leaves a sinus-shaped fill channel along the mid-line of the ventral surface 
of the phragmocone. This channel can extend through more than one whorl of the phragmocone, following the spiral line of the shell. In such cases the sedimentary rilling of the chambers of adjacent whorls is separated by the wall of the shell and the "sinus channel" is usually better developed in the more apical chambers. On the contrary, the annular furrows are only developed on the ventral surface of the last preserved whorl, never on the preceding one (Fig. 4). The surface of the ellipsoidal facets and annular furrows cuts the sedimentary filling of the chambers and septa of the phragmocone. Furthermore, its variations in shape do not coincide with the distribution of the septa, it is always deeper at the last third of the last preserved whorl and can progress centripetally towards the whorl sides of the last two adjacent whorls (Fig. 3C).

Some taphonomic features which permit the interpretation of ellipsoidal facets and annular furrows as structures developed on an early cemented internal mould of ammonite, or concretionary steinkern, during a subsequent interval of exhumation and before the final burial. These features include the presence of wear surfaces cutting the fabric of the sedimentary filling (Fig. 5) and the presence of a counterpart impression in the enclosing rock. The problem is essentially to explain the particular conditions of development of such structures and the way by which concretionary internal moulds acquired these abrasion surfaces during reworking processes.

Abrasion, or physical grinding, results in the rounding of skeletal remains and loss of superficial ornamental details (Brett, 1990). In rolled skeletal remains, the abrasion generally begins at the most prominent parts ofthe surface. Nevertheless, skeletal elements may be polished or abraded on only one side. This process is called faceting, and the shape and position of the facet is determined by both the abrading agent and the properties of the abraded element. Müller (1979) distinguished three main types of abrasion facets: (1) Anchor facets, (2) roll facets, and (3) glide facets, depending on whether they have been formed while the preserved elements were either fixed, rolling, or sliding on the substratum surface.
Anchor facets are produced when the skeletal remains are anchored to the substratum and projecting above its surface. If they are firmly fixed and partly exposed, faceting affects their upper side. The position of the facets depends on the orientation and the inclination of the partly exposed remains. Stably anchored skeletal remains are abraded down from the top. The progressive grinding of the upper surfaces of the shells or internal moulds may eventually lead to the development of a truncation surface parallel to bedding. The terms capping (Seilacher, 1971) and truncation by denudation (Fernắndez-López, 1985a), have been proposed for these process.

These truncational facets are a classic geopetal criterion for stratigraphic analysis, when the fossil is in the original position of burial and the facet is consistent with the stratification surface (Fig. 6). However, if the facet is non-consistent with the stratification surface, it can be used as an evidence of reworking (Fig. 7; cf. Seilacher, 1963, 1966, 1971; Seyfried, 1981; Meléndez et al., 1982; Mensink and Mertmann, 1984; Fernández-López, 1985a). Ellipsoidal abrasion facets and annular

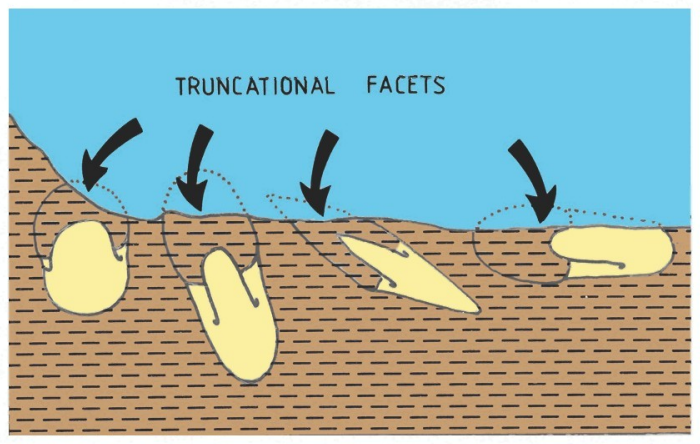

Fig. 6. Development of truncational facets. Fossils embedded in a firm or hard sediment being denuded, will develop a truncational facet as they are carved downwards from the top. The orientation and inclination of the fossil determines the particular location of these truncational facets which coincides and is continuous with the stratification surface. On the other hand, the fabric of both the fossil and the sediment will also show a physical and petrographical continuity. The position of the facets will be consistent, as well, with the geopetal structures of the internal moulds. In the case that internal moulds displaying ellipsoidal facets and annular furrows were submitted to these abrasion processes it would be very improbable that the facets were localized on the venter surface of the last preserved whorl and that the ornamentation would be preserved on both sides when the mould acquired an annular furrow. 


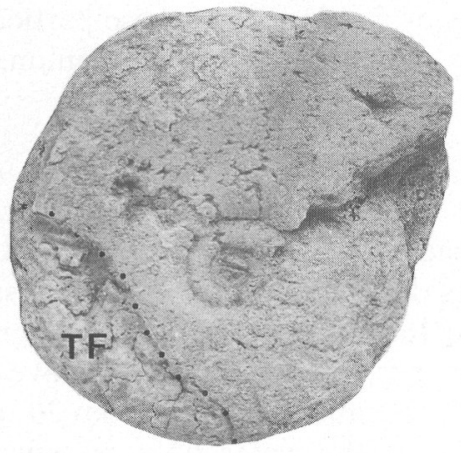

Fig. 7. Reworked internal mould of Leioceras sp. displaying a truncational facet $(T F)$ on the second half of the left side, in a non-consistent position with the stratification surface. This means that, before final burial, the concretionary mould had to be exhumed, abraded, mobilized, and overturned. Lower Aalenian (Col. SFL, LV2/1). x 1.

abrasion furrows cannot be considered as truncational facets, since they are preferentially developed on the last third of the last whorl. Unlike the truncational facets, these facets and furrows progress along the venter surface inward, and the ornamentation is always preserved on both whorl sides.

A different type of facets observed in reworked concretions and displayed as a sill line or "meniscus" marks has been described by Baird (1975). Such facets have been interpreted as evidence of partial exhumation of these concretions during erosion events and would indicate the lower limit of sediment removal during the time of formation of a stratigraphic diastem. If the internal moulds described here were partially exhumed as a consequence of the washing away of the sediment, but still fixed to the substratum, the portions of the internal moulds most exposed to the current flux should be the most abraded. In this case, facets would not be preferentially developed on a particular part of the internal moulds and even globular sphaerocones could acquire one or more facets in separate regions, according to the orientation of the internal mould during the exhumation process. Conversely, ellipsoidal facets and annular furrows are localized abrasion surfaces, preferentially developed in the venter on the last third of the preserved whorl, with the ornamentation preserved on both sides, and are restricted to discoidal moulds. Furthermore, these internal moulds are always physically and petrographically discontinuous with the fabric of the enclosing rock and the facets are neither coincident nor continuous with the stratification surface.

If internal moulds were not able to move freely on the depositional surface after exhumation, or if turbulence inducing their removal was caused by wave (oscillatory) currents, it would be very unlikely that abrasion surfaces would be localized on the venter surface of the last third of the last preserved whorl, and the ornamentation of the whorl sides or the most prominent portions would, most probably, be abraded as well. Consequently, internal moulds would normally be able to move freely on the depositional surface and had to be submitted to the action of directional (nonoscillatory) currents during the development of the ellipsoidal facet or the annular furrow.

Under the action of a directional water current, skeletal elements moving freely on the depositional surface will tend to orientate according to a mechanically more stable position (depending, of course, on the nature of the substratum). Any change in their position, or in the direction of the water current, will lead to the development of different abrasion facets. Rotation of the skeletal remains along a horizontal axis on the substratum may result in overturning of the elements or in an imbrication, whereas rotation along a vertical axis will result in a new azimuthal orientation or in an alignment of the elements. In both cases, the skeletal elements will tend to acquire a mechanically more stable position. This means maximal stability and minimal resistance to the water current. When the moved elements possess some projection acting as an anchor, they tend to turn on it until this turning point is oriented upstream. The reorientation of planispiral shells of cephalopods under the action of directional water currents has been studied in detail by several authors (e.g. Brenner, 1976; Futterer, 1978). However, in any taphonomic analysis concerning the processes of reorientation, special attention should be paid to the differential behavior of resedimented shells and reworked moulds (Fernández-López, 1985a, 1991b). 


\section{Formation of ellipsoidal facets and annular furrows}

The equilibrium position of ammonite shells and internal moulds depends largely on the relative position of the geometric center and the center of gravity respectively. Shells and internal moulds of the same shape and size have the geometric center placed in equivalent points (cf. Raup and Chamberlain, 1967; Saunders and Shapiro, 1986). However, equilibrium orientations assumed for ammonite shells are not applicable to internal moulds because shells and internal moulds of the same shape and size do not have the center of gravity in equivalent points (Fernández-López, 1985a). In internal moulds, the center of gravity is placed much farther from the geometric center, towards the last part of the preserved whorl, than in empty shells. In both cases, the center of gravity and the geometric center will tend to become oriented parallel to the flow direction. Nevertheless, in empty shells, both centers are so close together that their position of maximum stability is with the aperture or the last part of preserved whorl oriented downstream, as this is also the position of minimal resistance to the current (Fig. 8A). Conversely, the internal moulds show an opposite trend. The relative position of the center of gravity with respect to the geometric center of the internal moulds will cause them to reorient with the last part of the preserved whorl directed upstream (Fig. 8B).

Consequently, under the action of directional (non-oscillatory) water currents, the more stable azimuthal orientation of the internal moulds is diametrically opposed to that of shells. Due to this differential reorientation, it should be expected that the parts being preferentially abraded would be localized in diametrically opposed positions in resedimented shells and reworked internal moulds. For these reasons, both ellipsoidal facets and annular furrows appearing on internal moulds of ammonites are here interpreted as a special case of anchor faceting (sensu Müller, 1979, p. A26) developing on pivoting internal moulds subjected to directional water currents. However, the term "rotational faceting" could more properly describe the process of developing of these particular abrasion surfaces (C.E. Brett, pers. commun., 1993).

\section{Intrinsic factors}

The capacity of the internal moulds to acquire these facets during the reworking process depends on some features such as their specific gravity and size. In fact, such abrasion surfaces have only been observed in specimens ranging from 20 to $250 \mathrm{~mm}$ in diameter. If the water flow exceeds a certain threshold velocity, the ammonite moulds will tend to orientate preferentially. However, as the weight of moulds increases more rapidly than their surface of exposition to the current, any increase in the size of the elements will result in an increase of their mechanical stability and a correlative decrease of their capacity to reorient. This will make more unlikely the development of ellipsoidal facets and annular furrows in the largest specimens. In a similar way, the most probable behaviour of the smallest internal moulds would be freerolling on the depositional surface, rather than azimuthal reorientation. These behavioral constraints are linked to the size of the internal moulds and will result in ellipsoidal facets and annular furrows being restricted to narrow size ranges (from 20 to $250 \mathrm{~mm}$ ).

Observed specimens bearing ellipsoidal facets or furrows correspond to planispiral shells showing a ratio of thickness to diameter between 0.35 and 0.60 . They are most commonly platycones, rarely oxycones and never globose sphaerocones. Shape and eccentricity of the internal moulds are also important factors controlling reorientation parallel to the current flow and hence development of abrasion surfaces on the moulds. Evolute discoidal forms are more easily reoriented in this way than involute sphaerocones. Moreover, among internal moulds able to acquire abrasion facets, it is worth noting that the narrower the venter, the less probable is the development of an annular abrasion furrow.

\section{Extrinsic factors}

The development of the ellipsoidal facets and annular furrows also requires some particular 


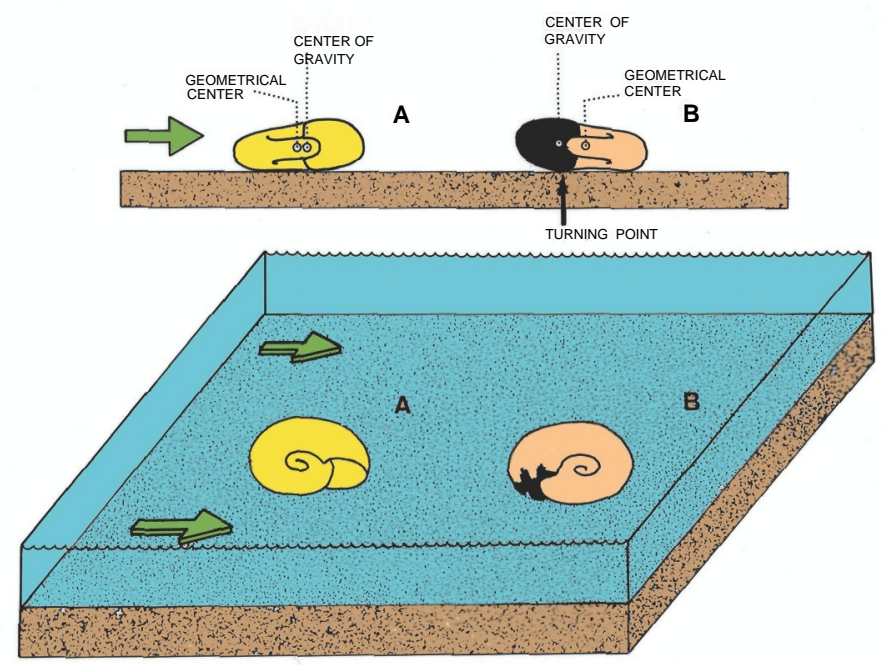

Fig. 8. Differential behavior of unfilled planispiral shells (A) and internal moulds (B) during reorientation processes. In both cases they will tend to orient with the longitudinal axis parallel to the water current, but in an opposite sense. In the case of shells, the center of gravity and the geometric center are so close together that their position of maximum stability will be with the last part of the preserved whorl oriented downstream. Conversely, in internal moulds the center of gravity is more distant from the geometric center, towards the last part of the whorl. This will make them to turn on this point and reorient upstream.

extrinsic factors. Hydraulic reorientation of internal moulds requires them to be exhumed and moved. The development of abrasion surfaces of these categories would not take place if there had been any interference between different internal moulds to inhibit their free displacements, or if they had settled on a soft or irregular substratum. The development of ellipsoidal facets and annular furrows would require a consolidated substratum, just firm enough to allow the internal moulds to move freely. The threshold velocity of surrounding sediment must be higher than for the internal moulds, or otherwise the internal moulds will sink or rotate into the substratum by settling into scours formed around them (Futterer, 1978; Kidwell and Bosence, 1991, p. 155). It follows that, once exhumed and free of matrix, internal moulds have to be subjected to directional (nonoscillatory) water currents and rest on a uniform, consolidated substratum, moving freely without interferences among them, in order to acquire these specific abrasion facets.

\section{Environmental conditions}

If, in addition to that, internal moulds bearing such facets or furrows show scarce evidence, or no evidence at all, ofrounding on the whorl sides and on the edges, it would mean that the turbulence regime able to generate the facets would be practically restricted to the proximity of the venter, showing a minimal influence on the whorl sides. Internal moulds abraded under such conditions will first develop an ellipsoidal facet and then, as abrasion proceeds, the worn area will also progress along the venter surface, from the last part of preserved whorl inward. This process will eventually result in the internal moulds showing a complete annular furrow. Progressive physical grinding during taphonomic reworking would result in ellipsoidal facets adopting the appearance of an annular furrow. Such hydrodynamic conditions require the water layer and the thickness of the mould to be similar, in order not to abrade its upper side. Consequently, the hydraulic conditions needed for 
the development of the ellipsoidal abrasion facets and the annular furrows would be present only in extremely shallow environments, intertidal environments being the most favorable (Fig. 9).

Besides the ornamentation displayed on the whorl sides by these reworked moulds, some other details, such as the angular shape and the sharp edges of facets and furrows can be used as criteria to exclude a long transport of the concretionary internal moulds before their final burial. Internal moulds with ellipsoidal facets and annular furrows with rounded edges and a higher degree of sphericity indicate later regimes of higher turbulence. However, it should be noted that some fossils showing rounded facets and a higher sphericity may have undergone several episodes ofreworking in different environments without being transported. For these reasons, in the case of abraded moulds, the degree of rounding of the edges in ellipsoidal facets and annular furrows reflects the duration and intensity of abrasion rather than the degree of allochthony.
If the abrasion processes took place in shallow subtidal environments, the action of the water currents would lead to the development of other types of facets (Fig. 10). If the turbulence regime was produced by wave (oscillatory) action, involving rolling and tumbling of reworked internal moulds on the substratum, abrasion would begin at their most prominent portions and the degree of rounding and sphericity would increase instead of decrease. In this case, free rolling of reworked moulds on the depositional surface would lead to the development of roll facets (Fig. 11). Under the action of directional (non-oscillatory) currents in shallow subtidal conditions, ornamentation on the whorl sides would be worn away and abrasion facets would not be localized on the last third of the last preserved whorl, the edges of the facets would be less sharp, and the development of annular furrows would be very unlikely. In this case, internal moulds anchored to the depositional surface would rather acquire truncational facets.

Finally, hydrodynamic conditions in a deep sub-
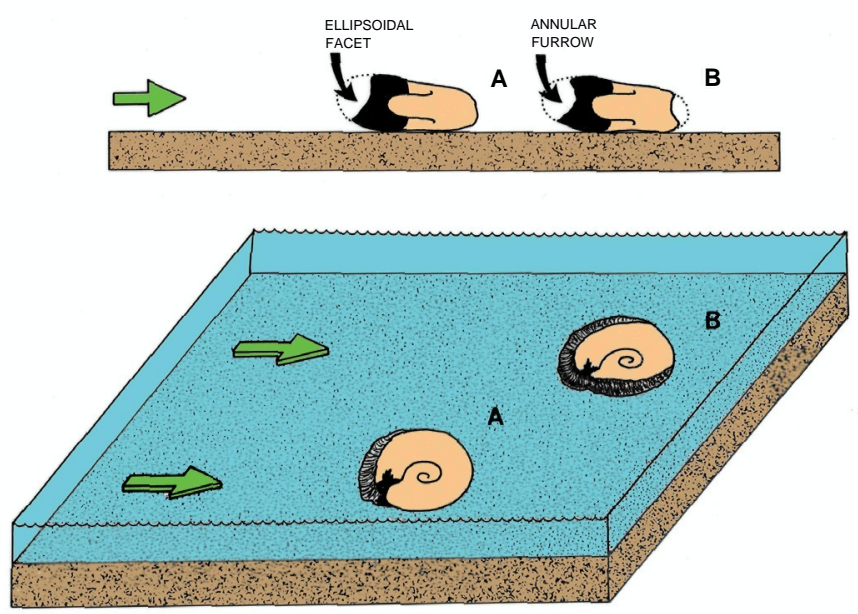

Fig. 9. Summary of the development of ellipsoidal abrasion facets (A) and annular abrasion furrows (B) on concretionary moulds of ammonites. Both types of abrasion surfaces develop on free-turning internal moulds, when subjected to directional concretionary moulds water currents. Once exhumed and free ofmatrix, and settled on a firm, uniform and consolidated substratum, the concretionary moulds should be able to reorient with the last part of the preserved whorl directed upstream, and hence being differentially abraded. An ellipsoidal facet would be first developed, and then the worn area would progress along the venter to carve a true annular furrow. The water layer should not be thicker than the thickness of the internal mould, so the ornamentation is preserved on the upper side of the internal mould. Consequently, the particular hydraulic conditions needed to abrade ellipsoidal facets and annular furrows would be present only in extremely shallow bathymetric conditions, intertidal environments being the most favorable. 

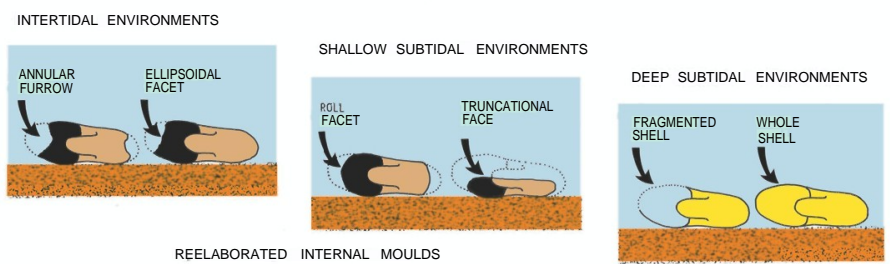

RESEDIMENTED SHELLS

Fig. 10. Diagrammatic sketch linking the described abrasion surfaces with environmental conditions. Annular furrows and ellipsoidal facets carved on the internal moulds of ammonites would develop by the action of directional currents under extremely shallow conditions, intertidal environments being the most favorable. In a shallow subtidal environment, under the action of a wave (oscillatory) currents, concretionary moulds would tend to overturn and develop roll facets. Under the action of bottom currents, internal moulds of ammonites would tend to be eroded on one side and to develop truncational facets. In a deeper subtidal environment, under a low turbulence regime, reworking processes would be unlikely and the most common elements would be either fragmented or complete shells.

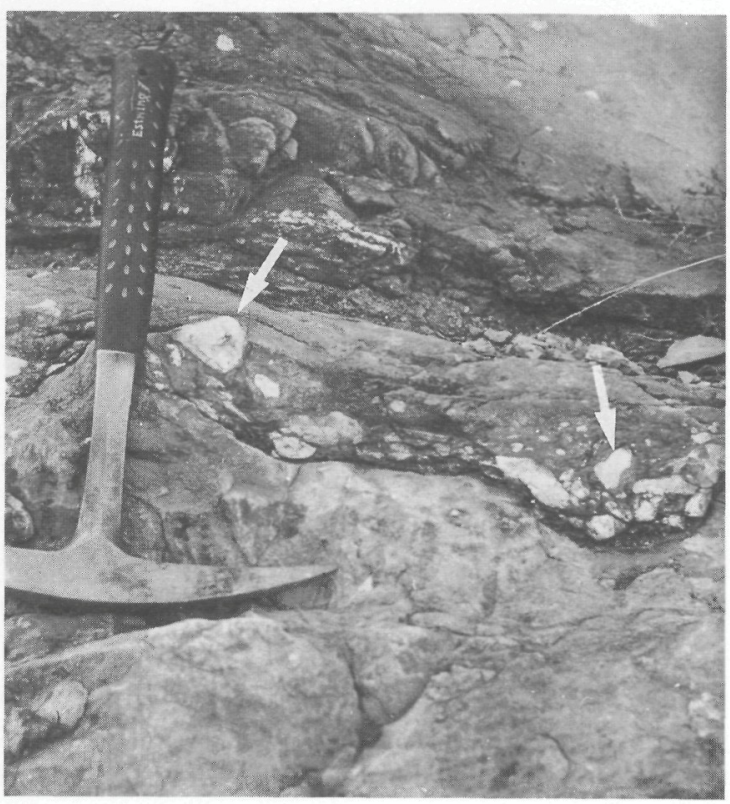

Fig. 11. Detail of a remobilization level from the lower Bajocian, Sauzei Zone, containing common reworked internal moulds of ammonites (arrowed). Reworked internal moulds show a certain degree of rounding and sphericity, indicating reworking in a shallow subtidal environment, under the determinant action of wave, oscillatory currents.

tidal environment would involve a low turbulence regime not strong enough for reworking the internal moulds on the depositional surface. In such conditions, the most common elements to be found would be either fragmented or complete shells.

\section{The use for sequence stratigraphy analysis}

Abrasion surfaces on internal moulds of ammonites can be used as a tool to identify and interpret sedimentary sequences. Due to the inferred hydrodynamic conditions, they can be extremely useful for recognizing trends within sedimentary sequences, stratigraphic discontinuities, and palaeogeographic conditions in which reworking processes took place.

During the reworking process, many internal moulds bearing ellipsoidal abrasion facets or annular abrasion furrows were buried again and incorporated into a new sediment within a sedimentary sequence developed under subtidal conditions. Therefore, these reworked fossils are, in fact, the only remaining evidence of inter- to supratidal conditions for sedimentary episodes not represented in the stratigraphic record of the basin. Reworked ammonites showing these wear surfaces are commonly associated with resedimented fossils at the base of shallowing upwards sequences. These mixed associations are condensed fossil assemblages, in which the reworked fossils are older than those resedimented, and the age of the bed containing the condensed assemblage of this kind is that of the resedimented fossils.

Some features, such as the increasing relative frequency of reworked vs. resedimented fossils towards the top of a sedimentary sequence, as well as the occurrence of specimens with ellipsoidal facets or annular furrows in the upper and in the 


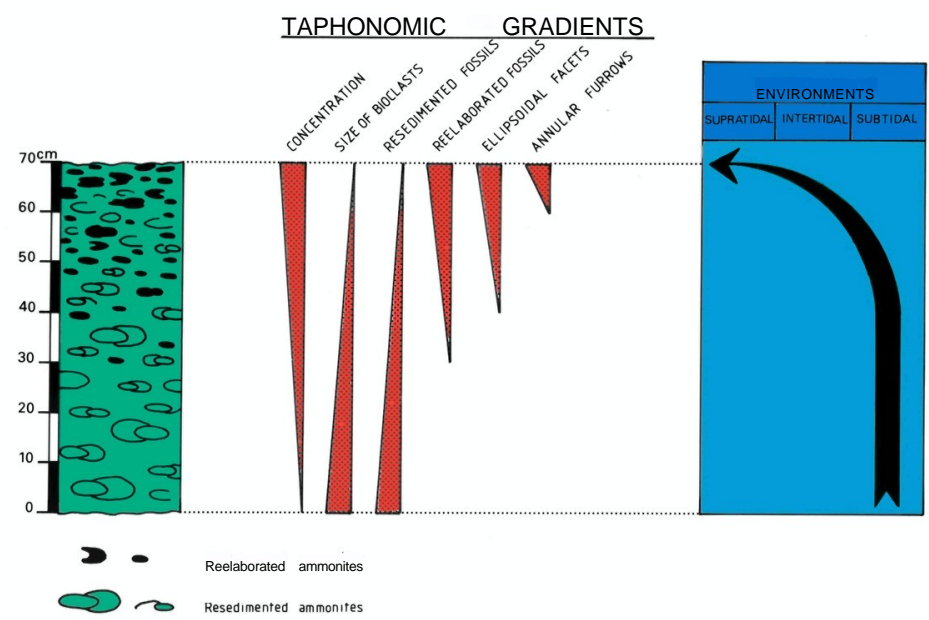

Fig. 12. Taphonomic gradients shown by the successive ammonite associations in a shallowing-upward sequence from the lower Callovian (Macrocephalus and Gracilis zones, after Fernández-López et al., 1978) of Sierra de Albarracin (Teruel, Spain), and the corresponding palaeogeographical interpretation It is worthnoting the progressively decreasing size and increasing concentration of ammonite bioclasts towards the top of the sequence, which can be erroneously interpreted as typical features of a deepening upwards sequence. However, taking into account the increase in the frequency of reworked fossils and the decrease of resedimented ones towards the top of the sequence, as well as the presence of specimens showing ellipsoidal facets and annular furrows in the upper terms, a shallowing upwards sequence, progressively evolving from subtidal to inter- or even supratidal environments, is more likely.

basal beds of the sequences, are common on the shallowing-upward sequences of the Middle Jurassic of the Iberian Range (Fig. 12). The increasing relative frequency of reworked vs. resedimented fossils occurs because concretionary internal moulds have a higher degree of durability (they are heavier and more resistant to the destruction by physical, chemical and biotic agents) than aragonitic shells during episodes of higher turbulence, even when these episodes took place in subaerial conditions. The second feature, the occurrence of specimens with ellipsoidal abrasion facets and annular furrows in the upper beds of the sequences, reflects a trend towards very shallow, inter- to supratidal, conditions. These taphonomic features are so conspicuous that they can be used as a tool to recognize and interpret the trends and discontinuities within the sedimentary sequences. Consequently, the transition from an assemblage consisting of resedimented and reworked ammonites with truncational facets or roll facets to a second assemblage containing ammonites with ellipsoidal abrasion facets or annular abrasion furrows is indicative of shallow- ing from subtidal to inter- or even supratidal environments. These taphonomic gradients are useful criteria in sequence stratigraphic analysis and in palaeogeographic reconstructions.

Ammonites with ellipsoidal abrasion facets and annular furrows have been reported, so far, only in the Iberian Range but they probably occur in other sedimentary basins as well. The recorded lateral and vertical variations of the fossils in a stratigraphic sequence should be taken into account in sequential analysis. The identification of these taphonomic gradients will help understanding of the differential completeness of the fossil record vs. the stratigraphic record, as well as help dating the discontinuities and provide an additional tool in Sedimentology and in palaeogeographic analysis.

\section{Conclusions}

Two categories of wear surfaces observed on Jurassic ammonites of the Iberian Range indicate that these fossils have undergone taphonomic 
reworking, i.e., the exhumation and displacement of the internal moulds before their final burial. These wear surfaces are classified as: (1) ellipsoidal abrasion facets, preferentially developed on the last third of the last whorl, and (2) annular abrasion furrows carved on the venter surface. The ammonites bearing abrasion surfaces of these categories are older than the bed containing them.

Ellipsoidal abrasion facets and annular abrasion furrows are interpreted as special cases of anchor facets (sensu Müller, 1979, p. A26), developed on pivoting internal moulds subjected to directional water currents. The term "rotational faceting" could more properly describe this process. The hydraulic conditions inferred for their formation would only occur in extremely shallow bathymetric positions, intertidal environments being most favorable.

The increasing relative frequency of reworked vs. resedimented fossils towards the top of sedimentary sequences constitutes a useful taphonomic criterion to recognize shallowing upwards sequences and their discontinuities.

The lateral and vertical variations in the stratigraphic distribution of reworked fossils reflect and can be correlated with trends within sedimentary sequences. A transition from associations comprising resedimented and reworked ammonites with truncational facets or roll facets towards a further association dominated by reworked ammonites with anchor facets, such as ellipsoidal facets or annular furrows (which can, in turn, be abraded and rounded), is indicative of shallowing gradients from subtidal to inter- or even supratidal environments.

\section{Acknowledgements}

This paper is a contribution to the projects Instalación y sustitución de plataformas carbonáticas y espongiolíticas durante el Lias-Dogger en el sector septentrional de la Cordillera Ibérica (DGICYT, P.B. 87-0546) and Reconstrucción evolutiva de los ecosistemas del Jurásico Superior en el sector nororiental de la Cordillera Ibérica (CONAI, Gobierno de Aragón, P. CB6/89). Financial support for the field work was also provided by the Instituto de Estudios Turolenses (CSIC, Teruel). Special thanks are due to Dr. Kevin Page (English Nature, Peterborough) for his critical reading of the manuscript, and to Profs. C.E. Brett (University of Rochester, New York) and F.T. Fürsich (Institut fur Paläontologie, Würzburg) for their numerous useful suggestions which helped much to improve the manuscript.

\section{References}

Aurell, M., 1990. El Jurásico superior de la Cordillera Iberica central (Provincias de Zaragoza y Teruel). Analisis de Cuenca. Tesis Dep. Ciencias de la Tierra, Univ. Zaragoza, $510 \mathrm{pp}$.

Aurell, M. and Meléndez, G., 1990. Upper Jurassic of the northeastern Iberian Chain (E. Spain); a synthesis. Seminarios de Paleontología, Univ. Zaragoza (SEPAZ), 2: 5-33.

Aurell, M., Fernández-López, S. and Meléndez, G., 1992. The Middle-Upper Jurassic oolitic ironstone level in the Iberian Range (Spain). Eustatic implications. Geobios, in press.

Baird, G.C., 1975. Coral encrusted concretions: a key to recognition of a "shale on shale" erosion surface. Lethaia, 9: 293-302.

Baird, G.C. and Brett, C.E., 1986. Erosion on an anaerobic seafloor: Significance of reworked pyrite deposits from the Devonian of New York State. Palaeogeogr., Palaeoclimatol., Palaeoecol., 57: 157-193.

Brenner, K., 1976. Ammoniten-Gehäuse als Anzeiger von Palaeo-Strömungen. N. Jahrb. Geol. Paläontol. Abh., 151: 108-118.

Brett, C.E., 1990. Destructive taphonomic processes and skeletal durability. In: D.E.G. Briggs and P.R. Crowther (Editors), Paleobiology, a Synthesis. Blackwell, Oxford, pp. 223-226.

Duringer, Ph., 1982. Les remplissages sédimentaires des coquilles de céphalopodes triassiques. Mécanismes et intérêt paléoécologique. Geobios, 15: 125-145.

Eshet, Y., Druckman, Y., Cousminer, H.L., Habib, D. and Drugg, W.S., 1988. Reworked palynomorphs and their use in the determination of sedimentary cycles. Geology, 16: 662-665.

Fernández-López, S., 1985a. Criterios elementales de reelaboración tafonómica en ammonites de la Cordillera Ibérica. Acta Geol. Hisp., 19(1984): 105-116.

Fernảndez-Lopez, S., 1985b. Séquences sédimentaires et séquences taphonomiques. Strata, 2: 116-122.

Fernảndez-Lopez, S., 1985c. El Bajociense en la Cordillera Ibérica. Tesis Dep. Paleontología, Univ. Complutense, Madrid, $850 \mathrm{pp}$.

Fernảndez-Lopez, S., 1991a. Taphonomic concepts for a theoretical biochronology. Rev. Esp. Paleontol., 6: 37-49. 
Fernández-López, S., 1991b. Sistemas tafonómicos: función y evolución. Rev. Esp. Paleontol., No. Extraord., pp. 21-34.

Fernández-López, S. and Gómez, J.J., 1990a. Facies aalenienses y bajocienses, con evidencias de emersión y carstificación, en el sector central de la Cuenca Ibérica. Implicaciones paleogeográficas. Cuad. Geol. Ibérica, 14: 67-111.

Fernández-López, S. and Gómez, J.J., 1990b. Utilidad sedimentológica y estratigráfica de los fósiles reelaborados. In: S. Fernández-López (Coordinator), Comunicaciones de la Reunión de Tafonomía y Fosilización. Dpto. Paleontol., Univ. Complutense, Madrid, pp. 125-144.

Fernández-López, S., Meléndez, G. and Suarez-Vega, L.C., 1978. El Dogger y Malm en Moscardón (Teruel). Grupo Español de Mesozoico, Jurásico Cordillera Ibérica, VI, 23 pp.

Futterer, E., 1978. Studien über die Einregelung, Anlagerung und Einbettung biogener Hartteile im Strömungskanal. N. Jahrb. Geol. Paläontol. Abh., 156: 87-131.

Henderson, R.A. and Mcnamara, K.J., 1985. Taphonomy and ichnology of cephalopod shells in a Maastrichtian chalk from Western Australia. Lethaia, 18: 305-322.

Kidwell, S.M. and Bosence, W.J., 1991. Taphonomy and timeaveraging of marine shelly faunas. In: P.A. Allison and D.E. Briggs (Editors), Taphonomy, Releasing the Data Locked in the Fossil Record. Plenum, New York, pp. 115-209.

McCaffrey, W.D., Barron, H.F., Molyneux, S.G. and Kneller, B.C., 1992. Recycled acritarchs as provenance indicators: Implications for Caledonian terrane reconstruction. Geol. Mag., 129: 457-464.

Meléndez, G., Sequeiros, L. and Brochwicz-Lewinski, W., 1982. Lower Oxfordian in the Iberian Chain, Spain. Part I: Biostratigraphy and nature of gaps. Bull. Acad. Pol. Sci., 30: 157-172.

Meléndez, G., Aurell, M., Fontana, B. and Lardiés, D., 1990. El tránsito Dogger-Malm en el sector nororiental de la Cordillera Ibérica: Análisis tafonómico y reconstrucción paleogeográfica. In: S. Fernández-López (Coordinator), Comunicaciones de la Reunión de Tafonomía y Fosilización. Dpto. Paleontol., Univ. Complutense, Madrid, pp. 221-229.

Mensink, H. and Mertmann, D., 1984. Diskontinuitäten im unter-Callovium der nordwestlichen Keltiberischen Ketten (Spanien). N. Jahrb. Geol. Paläontol. Abh., 167: 189-223.

Müller, A.H., 1979. Fossilization (Taphonomy). In: R.A.
Robinson and C. Teichert (Editors), Treatise on Invertebrate Paleontology. Part A. Introduction. Geol. Soc. Am. and Univ. Kansas, Boulder, CO, pp. A2-A78.

Mundlos, R., 1970. Wohnkamerfüllung bei Ceratitengehäusen. N. Jahrb. Geol. Paläontol. Monatsh., 1970: 18-27.

Needham, H.D., Habib, D: and Heezen, B.C., 1969. Upper Carboniferous palynomorphs as a tracer of red sediment dispersal patterns in the northwest Atlantic. J. Geol., 77: $113-120$.

North American Commission on Stratigraphic Nomenclature, 1983. North American Stratigraphic Code. Bull. AAPG, 67: 841-875.

Raup, D.M. and Chamberlain, J.A., Jr., 1967. Equations for volume and center of gravity in ammonoids shells. J. Paleontol., 41: 566-574.

Saunders, W.B. and Shapiro, E.A., 1986. Calculation and simulation of ammonoid hydrostatics. Paleobiology, 12: 64-79.

Scott, D.B. and Medioli, F.S., 1988. Tertiary-Cretaceous reworked microfossils in Pleistocene glacial-marine sediments: An index to glacial activity. Mar. Geol., 84: 31-41.

Seilacher, A., 1963. Umlagerung und Rolltransport von Cephalopoden-Gehäusen. N. Jahrb. Geol. Paläontol. Monatsh., 1: 18-27.

Seilacher, A., 1966. Lobenlibellen und Füllstruktur bei Ceratiten. N. Jahrb. Geol. Paläontol. Monatsh., 125: 480-488.

Seilacher, A., 1968. Sedimentationsprozesse in AmmonitenGehäusen. Akad. Wiss. Lit., Abh. Math.-Naturw. KL, 1967, 9: 191-203.

Seilacher, A., 1971. Preservational history of ceratite shells. Palaeontology, 14: 16-21.

Seyfried, H., 1981. Genesis of "regressive" and "transgressive" pelagic sequences in the Tethyan Jurassic. In: A. Farinaci and S. Elmi (Editors), Rosso Ammonitico Simp. Proc. Tecnosciencia, Rome, pp. 547-579.

Stanley, E.A., 1965. The use of reworked pollen and spores for determining the Pleistocene-Recent and the intraPleistocene boundaries. Nature, 206: 289-291.

Stanley, E.A., 1966. The problem of reworked pollen and spores in marine sediments. Mar. Geol., 4: 397-408.

Traverse, A., 1988. Paleopalynology. Unwin Hyman, Boston, 600 pp. 